\title{
Mental Retardation, Autosomal Dominant
} 39

National Cancer Institute

\section{Source}

National Cancer Institute. Mental Retardation, Autosomal Dominant 39. NCI Thesaurus.

Code C156309.

An autosomal dominant condition caused by mutation(s) in the MYT $1 \mathrm{~L}$ gene, encoding myelin transcription factor 1-like protein. It is characterized by intellectual disability and mild dysmorphic facial features. 